NBER WORKING PAPER SERIES

\title{
FOREIGN EXCHANGE RATE EXPECTATIONS: MICRO SURVEY DATA
}

Takatoshi Ito

Working Paper No. 2679

NATIONAL BUREAU OF ECONOMIC RESEARCH 1050 Massachusetts Avenue

Cambridge, MA 02138

August 1988

Discussions with Jeffrey A. Franke1, Kenneth A. Froot, Hidehiko Ichimura, Maurice Obstfeld, and Christoper Sims were very useful. I have benefitted from comments received form participants of seminars at Harvard University, University of Minnesota, University of California at San Diego and National Bureau of Economic Research. I thank the Japan Center for International Finance, especially President Tomomitsu Oba and Vice President Shoji Ochi, for having made the survey data in the Tokyo market available. Financial support from National Science Foundation grant number SES-8808828 and from Japan Economic Research Foundation, [Nihon Keizai Kenkyu Shorei Zaidan] is gratefully acknowledged. This research is part of NBER's research program in International Studies. Any opinions expressed are those of the author not those of the National Bureau of Economic Research. 
NBER Working Paper \#2679 .

August 11988

FOREIGN EXCHANGE RATE EXPECTATIONS:

MICRO SURVEY DATA

\section{ABSTRACT}

This paper analyzes the panel data of bi-weekly surveys, conducted by the Japan Center for International Finance, on the yen/dollar exchange rate expectations of forty-four institutions for two years. There are three major findings in this paper. First, market participants are found to be heterogeneous. There are significant "individual effects" in their expectation formation. Second, many institutions are found to violate the rational expectation hypothesis. Third, forecasts with long horizons showed less yen appreciation than those with short horizons. Cross-equation constraints implied by the consistency of the forecast term structure are strongly rejected in the data.

Takatoshi Ito

Institute of Economic Research

Hitotsubashi University

Kunitachi, Tokyo, 186 Japan 


\section{Introduction}

As rational expectations have beccme a popular bencimark in thinking financial and macroeconomic hypotheses, many economists have become more interested in directly measuring expectations of market participants Although survey data on many domestic variables, including interest rates and inflation rates, have been frequently analyzed by pany investigators (see, for example. Mishkin (1983; ch. 4)), it is only recently that survey data on foreign exchange rates have become available and been analyzed. Dominguez (1986) and Frankel and Froot (1987a,b) have exploited the survey data made available by the Money Market Service (MMS). the Amex Bank Review and the Economist Financial Report. 1

The surveys that were investigated by Dominguez. and by Frankel and Froot have only their median responses reported. Heterogeneity among the market participants, if it existed, is aggregated out. If the market consists of homogeneous agents which stare the same forecasting model with common belief (priors) and information, then the median response would sufficiently describe the market in terms of forecasts. However, if market participants differ in their forecasting characteristics, focusing on the median misses the wost interesting questions such as whehter the differences persist or are temporary, whether the difference is correlated with the participant's traits, and whether a rationality hypothesis is more likely to be rejected in individual data. Only individual responses of survey data could answer these questions.

In this paper, I will use the survey data collected by the Japan Center for International Finance (JCIF) in Tokyo, which allows me to investigate the individual responses in the survey. ${ }^{2}$ In particular the JCIF data set has two distinct advantages over other data used by Dominguez, and by 
Frankel and Froot. First. the JCIF data consist of indiridual responses with no missing observations. Second, not only financial institutions but other companies are polled in the JCIF survey. Therefore. there is a chance to associate possible heterogeneity to forecasters' industry traits.

There are three major findings in this paper. First. market participants are found to be heterogeneous. There are significant "individual effects" in their expectation formation. Second, many institutions are found to violate the rational expectation hypothesis. Most of them underestimated the degree of yen appreciation. Third. forecasts with long horizons showed less yen appreciation than ones with short horizons. Put differently, market participants appear to have a "bandwagon" expectation in the short-run, but a "stabilizing" one in the long-run. The "twist" in forecast term structure could be "internally consistent" (in the sense of Froot and Ito (1988)), if an iterated substitution of a short-term forecast yields a long-term forecast. However, cross-equation constraints implied by the internal consistency are strongly rejected in the data.

\section{Data Summary}

\section{A. The Data Description}

The JCIF has conducted a telephone survey twice a month, in the middle and the end of the month, on Wednesdays, since May 1985. Forecasts of the yen/dollar exchange rate for one-, three- and six-month horizons are obtained from foreign exchange experts in 44 companies; 15 banks and brokers, 4 securities companies, 6 trading companies, 9 export-oriented companies 5 life insurance companies, and 5 import-oriented industries. ${ }^{4}$ The survey It is meticulously arranged so that all 44 companies on the permanent list respond every week. 
When a data set is analyzed as a panel data. the mean across individuals and the mean across time should not be confused. In the following. the mean across forty-four individuals at a time will be referred to as an (cross-section. total) average: the mean across individuals at a time in an industry group will be referred to as a group average. The mean across time of an individual. of a group, or of the total "average" will be referred to as the (time) mean of the individual, of the group. or of the average, respectively.

The JCIF calculates the total average, standard deviation. maximum, and minimum of forty-four responses and also industry group averages and group standard deviations. On the day after the survey, the JCIF informs its members. including those who are polled, of the summary statistics. The overall (cross-section) average is also released to the press and other media

I will use, in addition to the panel data of forty-four companies. the pubiic information part of the survey: the cross-section average (AVE) of forty-four companies and group averages for different industries; banks (BAN), securities companies (SEC), trading companies [Sogo Shosha] (TRA). companies in the export industries (EXP), insurance companies (INS), and companies in the import industries (IMP). The unit is yen per one U.S. dollar, so that negative movement indicates yen "appreciation." The spot exchange rate, $s(t)$, is measured at the closing quote in Tokyo on wednesday of the survey week.

\section{B Overview}

Let us illustrate the average (aggregate) expectation and the movement of actual exchange rates during the one-year turbulent period following the Group of Five, Plaza Agreement of September 1985. In Figure 1, the solid 
Iine is the actual daily spot rate. while the base of each sequence of three arrows shows the timing of the poll and the spot exchange rate of that day Three arrows, respectively, point to the forecasted exchange rate (the average of the forty four) with the one-. three-and six-month horizons. Therefore, the vertical deviation of the tip of an arrow from the spot rate (solid) line represents an ex post mistake of the expectation.

\section{FIGURE 1 ABOUT HERE}

From this figure, two preliminary observations emerge. First, each of several waves of sharp appreciation does not seem to have been anticipared by the market. (See Ito (1987) for "news" analysis of these appreciation waves.) Second, the long-run expectation is not the simple extrapolation of the short-run expectations. In fact, there seems to be a "twist" in expectation term structure.

In order to quantify these observations and to extend observations to group aggregates and individual responses, Table 1 and Figure 2 are provided. Table 1 shows that the time means of (unconditional) expected changes (in percent) from the spot rate at the time of survey for the crosssection total average, group averages, and (in a separate distribution table) for each individual. For the purpose of discussion, the mean of forward premium (FOR) and the actual (ex post) changes of the spot exchange rate (ACT) for each horizon are reported in the same table. For each horizon and each individual or group, subtracting the forward premium from the forecasts yields the implied risk premium and subtracting the actual changes produces the forecast errors. 
In the one-month horizon, the (total, average on a typical week expected a 1.4 percent yen appreciation. The group averages ranged from 0.8 percent to 2 percent appreciation. In relative to total average. the export industry was most biased toward yen depreciation and trading companies and import industries were most biased toward yen appreciation. Looking into individual data, one extreme predicted 1.4 percent depreciation of ven. while the other extreme predicted 3.1 percent of appreciation. The distribution of individual forecasts has a nice unimodal distribution. The actual change is at about one-fifth in the distribution, that is. about 20 percent of participants overpredicted the size of yen appreciation in the one-month horizon.

The mean of forward premium (FOR) was 0.15 percent, indicating that there was a risk premium for most of the participants in favor of the dollar asset. The mean of actual changes for a one-month period was 2.1 percent during the two years of the sample period. The forecasts by trading companies with 2.0 percent and import companies with 1.9 percent came close to the actual movement. All groups and a majority of individuals did better in forecasting than the forward rate in the one-month horizon.

The expected appreciation of the yen in the three-month horizon for the average was 1.4 percent, about the same as the one-month horizon. (Note that no adjustment is made with respect to the length of horizon.) Hence, the aggregate forecasts, one-month and three-month combined, imply that they predict little movement after the first month to the third month in the forecast horizon. However, this statement will be qualified shortly when we examine the individual responses. The actual change was 6 percent appreciation in three months. The total and group averages underpredicted the size of yen appreciation by 3 to 5 percentage points. In fact, the most yen 
appreciation predicted by an individual is 4.8 percent. and no individual overpredicted the size of yen appreciation in the three-month horizon.

As in the one-month horizon. the export industry has a ven depreciation bias (from the total average), and the trading companies have a yen appreciation bias in the inree-month horizon. The implied risk premium shows that the export industry would have a negative risk premium for the dollar asset, while others have a positive risk premium as in the one-month horizon. This makes sense considering that exporters are long in dollar assets in the medium run.

Wide disagreement among individuals starts to show in the three-month forecasts. It becomes a bi-modal distribution: one group believes that the yen depreciates from the one-month to three-month in the forecast horizon. while the other believes that the yen continues to appreciate. The distribution also has long tails. Therefore, although the group averages for oneand three-month horizons predict a yen appreciation of about the same size (1.4 percent), distributions of individual responses are quite different. The last observation illustrates how important it is to have a data set with individual responses rather than one with the summary statistics.

For the six-month horizon, the total average practically shows that the market expects the yen to return to the prevailing level at the time of forecast. This is a sharp turnaround from the forecast of 1.4 percent yen appreciation in three months. In fact, each of the group averages indicates that the group anticipates less yen appreciation in the six-month horizon than either of the one- or three-month horizons. The agreement among different groups in forecasting the sharp yen appreciation from the third to the sixth month is quite striking, since they differ in forecasting the 
direction of the yen from the first to the third wonth.

In the six-month horizon, all of the groups have a negative risk premium for the dollar denominated asset. This contrasts to the positive risk premium in the one-month horizon.

The distribution of individuals is almost uniform ranging from a three percent depreciation to a one percent appreciation. highlighting a diversity of the individual forecasts. It is clear from the figure that the degree of diversicy increases as the forecast horizon is longer. Again looking at the average would not give this observation.

Findings of this section can be sumarized and related to the contents of the rest of this paper. First, the findings are highly suggestive of heterogeneous market participants. A rigorous analysis and interpretation of the heterogeneity will be provided in Section 3. Second. large forecast errors were recorded during the intermittent waves of yen appreciation after September 1985. However, when the exchange rate was relatively stable for a while, the one-month market expectation overpredicted the amount of appreciation. Therefore, it is not immediately clear from the figures whether expectations were unbiased. In Table 1, a comparison of group (or individual) time means with the actual change (ACI) shows the average forecast errors for each horizon. These observations are only suggestive without test statistics. Econometric tests on various forms of the rational expectation hypothesis will be conducted in Section 4.

Third, the short-horizon expectations seem to predict yen appreciation, while the long-horizon expectations seem to predict a reverse in direction. Thus, the total average and most of the group averages have a "twist" in their forecasts. Section 5 investigates whether such twists in expectations are internally consistent. 
3. Wishful Expectations and Heterogeneity

3.A. Econometric Issue $=$ a special case of panel data

Recall that our micro survey data set consists of forty-four individuals and fifty-one observations. Suppose that an individual forecast formation at time $t$ consists of the common structural part based on the public information, $f(I(t))$ and the individual effect. $e_{j}$. For a given forecast horizon, $\mathrm{k}$ (suppressed notation). the expected exchange rate for individual $j, j=1, \ldots . J$ (where in this paper $J=44$ ) is

$$
s_{j}^{e}(\tau)=f(I(\tau))+e_{j}+u_{j}(\tau)
$$

where $s_{j}^{e}(t)$ is a $k$-step ahead forecast of the spot exchange rate at $t$ ime $t$. by individual $j: u_{j}(t)$ is a pure random disturbance representing, for example, a measurement error. The cross-section average of individual forecasts, $s_{\mathrm{AVE}}^{e}(t)$ is defined as

$$
s_{\mathrm{AVE}}^{e}(t)=f(I(t))+e_{\mathrm{AVE}}+u_{\mathrm{AVE}}(t)
$$

where $s_{A V E}^{e}(t)=\left(E s_{j}^{e}(t)\right) / J, e_{A V E}=\left(E e_{j}\right) / J$ and $u_{A V E}=\left(\begin{array}{ll}E & u_{j}\end{array}\right) / J$. Assume $f(I(t))$ contains a constant term so that normalization, e eVE $=0$. is possible. Then subtracting each side of (3.2) from the corresponding side of (3.1), we obtain

$$
s_{j}^{e}(t)-s_{A V E}^{e}(t)-e_{j}+\left(u_{j}(t)-u_{A V E}(t)\right)
$$

The estimator of individual effect, $e_{j}$ can be obtained by regressing the lefthand side of (3.3) on a constant over the sample period (across time). This procedure is simple and robust. It is unnecessary for the econometrician to know the exact structure $f(I(t))$ as long as it is common 
to everybody for every survey date.

If the difference in the individual effects of two individuals is to be estimated, a similar method can be emploved.

$$
s_{j}^{e}(t)-s_{k}^{e}(t)=e_{j}-e_{k}+\left(u_{j}(t)-u_{k}(t)\right) \cdot k \neq j .
$$

Then the difference in the individual effect between the individual $j$ and $k$ is estimated by regressing the lefthand side of (3.4) on a constant term over the sample period (across time).

If the difference in individual beliefs extends to "idiosyncratic" coefficients on publicly available information in the structural part. $f(I(t))$, the above procedure needs to be modified, but is still applicable. Suppose, for example, that the forecast is in an extrapolative form:

$$
s_{j}^{e}(t)-s_{A V E}(t)=a_{j}+b_{1 j}(s(t-1)-s(t))+b_{2 j}(s(t-2)-s(t-1))+u_{j}(t)
$$

where $e_{j}$ is integrated in the difference in $a_{j}$. Then the idiosyncratic individual coefficients can be estimated by regressing the following equations:

$$
\begin{aligned}
s_{j}^{e}(t)-s_{A V E}^{e}(t) & =a_{j}-a_{A V E}+\left\{b_{1 j}-b_{1 A V E}\right\}(s(t-1)-s(t)) \\
& +\left(b_{2 j}-b_{2 A V E}\right)(s(t-2)-s(t-1))+u_{j}(t)-u_{A V E}
\end{aligned}
$$

The above procedure parallels the technique in the panel data analysis. although, in the usual examples of the panel data analysis, the common structure has the different input amount (such as labor and capital) observable to econometricians. Instead, it is reasonable here to assume that the structural part and values of regressors (i.e., past values of the exchange rates) in exchange rate forecasts are identical for all individuals, but with possibly different coefficients. This, on the one hand, simplifies the estimation of individual effects, but on the other hand 
makes a time effect impossible to detect. Since the value of regressors. that is past exchange rates, are comon for all individuals, a cross-section regression or other techniques to detect a time effect cannot be applied in our panel data.

\section{B Heterogeneous Participants in the Tokyo Market}

In search of hard evidence for (or against) heterogeneity among market participants, I estimate forty-four individual effects. $e_{j}$, and also "group effects." In detecting the "group effect," a group average forecast calculated by the JCIF is treated as an individual $j$, then the total average (or another group average) is subtracted. 5

The individual (or group) effect $e_{j}$ is estimated using equation (3.3) and reported in Table 2. Panels 2.A. and 2.B show the group effects. and panel 2.C. shows the distribution of individual effects.

Insert Table 2 about here

From panel 2.A., we learn that for any horizon, group effects are significant for the export industry, with an depreciation bias, and for the trading companies, with a appreciation bias. A significant appreciation bias was detected also for the import industry for the one-month horizon, for the insurance industry, and for the banking sector.

The distictive effect of exporters in contrast to importers or to trading companies can be highlighted by measuring the difference in individual effects directly, as in equation (3.4). This is done in panel 2.B. Again, this confirms that exporters have depreciation bias in their expectation formation in relation to importers and trading companies for any horizon. 
Panel 2.C shows that, for any horizon. about half of the forty-four individuals have a significant bias in their forecasts. Deviations are sometimes very large. One individual in the one-month horizon forecasted on average three percent depreciated than the average of the group. Similarly. one individual forecasted with a 5 percent depreciation bias in the threeand six-month horizons.

One might object to a formulation of individual effects in the form of biases in the constant term. They could have different models. Since it is not likely that the JCIF or the econometrician could persuade each forecaster to justify the forecast with the model every week, we have to guess the form, assuming that each market participant has a common autoregressive forecasting model, but with different coefficients on the lag terms (possibly because of the difference in their prior belief). As discussed above, idiosyncratic coefficients can be estimated from equation (3.6). The results are shown in Table 3.

Table 3 once again shows that exporters and trading companies are significantly heterogeneous for any of the three horizons. However, the difference comes from the bias in individual (constant term) effects, not from idiosyncratic coefficients of the lagged variables. Importers for the one-month horizon and the banks for the six-month horizon also show the individual (constant) effect, as in table $2 . \mathrm{A}$, but fail to show the idiosyncratic coefficients on the lagged variables. Therefore, the heterogeneity is more like a constant bias rather than the difference in how to react to the recent changes in the exchange rate. Table 2, panels A-C 
and Table 3, all combined, show solid evidence for heterogeneous expectation formations among market participants.

\section{C Discussion: Heterogeneity and Rational Expectations}

Most of the modern theory of finance or macroeconomics assumes the existence of the representative agent whose decision is an aggregate of market participants. In fact, the hypothesis of rational expectations would require that market participants be homogeneous in their formation of expectations, since the true stochastic process is unique. Therefore, findings of heterogeneity in this section cast some doubts to the framework using a homogeneous agent model commonly used in finance and macroeconomics.

If agents have private information which econometricians do not observe, the existence of individual effects may not be inconsistent with rational expectations. However, important news and variables in the foreign exchange market are mostly common knowledge. A likely explanation of heterogeneity, consistent with rational expectations, would be slow learning process due to a strong biased prior. Then, we need to consider how biases may be related to individual priors.

\section{D Discussion: Wishful Expectations}

Having established heterogeneity, a discussion of why certain market participants have depreciation or appreciation biases is in order. From Table 2.A and 2.B, we notice some regularity in the group effects. Market participants apparently form "wishful expectations." Exporters wish that the yen will depreciate in the future, enabling their profit margins to increase and their products to compete better in the foreign markets. Their responses to survey questions seem biased toward yen depreciation relative to the average. On the contrary, importers' responses reflect their wish 
for stronger yen so that import costs will decrease. ${ }^{6}$ The tendency of wishful expectations is evident in the one-month ahead forecasts. The exporters' forecasts show a continuing deviation from the mean, significantly biased toward yen depreciation. as the forecast horizon lengthens. In the three-month and six-month ahead prediction, trading companies, instead of importers, show a bias toward appreciation.

This "wishful expectation" may be a reflection of non-rational honest mistakes in expectation formation. A straightforward interpretation would be for respondents to mix wishful thinking with objective forecasts. There are a few deeper explanations of wishful expectations

The Japanese manufacturing and trading companies usually set an in-house exchange rate. which can be used for the sales department in calculating in-house accounting. It is possible that these in-house rates are heterogeneous, and moreover are slightly biased so that the sales department is encouraged. The survey responses from these companies may be influenced by the biased in-house exchange rate, although the respondent is not from the sales department.

If the announcement of the JCIF survey is very influential on the market, the respondent may be induced to try manipulating the announced survey result by answering with biased forecasts. Exporters respond to the JCIF by announcing the rate depreciated, though slightly to avoid obvious detection, in the hope that the survey mean is biased toward depreciation. Exporters hope that the mean expectation with an "unexpected" depreciating bias cause others to start selling yen, thus creating a self-fulfilling prophecy; if importers understand that exporters have incentives to lie. then importers would counter by manipulating their announcements; and vice 
yersa. Thus, as a Nash equilibrium. the mean mav not be biased after al1. although exporters and importers are biased.

Despite its appeal to economists who are trained to seriousiy think about expectation and manipulation. this story of a manipulative motive has a few shortcomings. First, the size of survey. i.e.. forty-four respondents, is large enough that a manipulation by one respondent insignificant unless the bias is large enough to be detected easily by the JCIF, If all exporters collude in their responses, it may escape easy detection. But the identity of respondents included in the survey is a secret. Second, if other participants understand that exporters and importers have incentives to lie, then they would not take the JCIE survey seriously, thereby removing the incentive to lie. It may be the case that market participants are simply naive in forming wishful expectations.

\section{Rationality of Expectations}

In this section, I will apply standard tests of rational expectation to this survey data, ${ }^{7}$ First, if forecasts are rational, the forecast errors should be random. In other words, survey forecasts should be unbiased. Second, given rational expectation, forecast errors should be uncorrelated with any information available at the time the forecast is made. Otherwise. the variable correlated with the ex post error could have been exploited to make better forecast. Put differently, forecast errors should be orthogonal to any variable in the information set at the time of forecasting.

Under the null hypothesis of rational expectation, the realized spot rate is the sum of a forecast and a Eorecast error:

$$
\mathbf{s}(t+\mathbf{k})-\mathbf{s}^{\mathrm{e}}(t, \mathbf{k})-\mathbf{e}(t, \mathbf{k})
$$

where $e(t, k)$ is mean zero forecast errors and uncorrelated with any 
variables available at $t$. It is well known that forecast errors. e(t.k). would be serially correlated if the forecast horizon is ionger than the observational frequency, i.e., k $>2$. Therefore, rational expectations imply $a-0$ and $b=1$ in the following regression:

$\left.s(t+k)-s(t)=a+b\left(s^{e}(t, k)-s t\right)\right)+u(t)$

The test statistics are calculated using the General Method of Moments to take care of the serial correlations of $u(t)$. Results of this unbiasedness test are reported in Table 4.

\section{INSERT TABLE 4 ABOUT HERE}

Unbiasedness is rejected for trading companies and insurance companies of the one-month horizon, for securities and import companies of the threemonth horizon, and for all groups but banks and import industries for the six-month horizon. These rejections are evidence for rejecting a rational expectation hypothesis, in that market participants had unbiased forecasts. We would miss some rejections if we were only to look at the average of the forty-four participants, since for the one-month and three-month horizons, rejections by some groups are not detected in the average for all participants.

The second implication of rational expectation is the orthogonality of forecast errors and any information at time $t$. Under the null hypothesis, forecast errors, $e(t, k)=s^{e}(t, k)-s(t+k)$, are uncorrelated from any information at time $t$. In the literature, the past forecast errors $s^{e}(t-k, k)-s(t)$; the forward premium, $f(t, k)-s(t)$; or the recent actual change $s(t-k)-s(t)$ have been popular candidates for a variable in the information set. In this section, I will follow the standard procedure by 
regressing the ex post forecast errors on these candidate variables.

$$
\begin{aligned}
& s^{e}(t, k)-s(t+k)=a+b\left(E s^{e}(t-k, k)-s(t)\right)+e(t) \\
& s^{e}(t, k)-s(t+k)=a+b(f(t, k)-s(t))+e(t) \\
& s^{e}(t, k)-s(t+k)=a+b(s(t-k)-s(t))+e(t)
\end{aligned}
$$

Rational expectation (orthogonality) is a null hypothesis of $a=b=0$ in each case. Results of estimation of these equations and tests of the nul1 hypothesis are reported in Tables 5.A- 5.C. In each piece of information. there are only a few instances of rejections of the one-month and three-monch horizons. However, for the six-month horizon, it is unanimous in rejection. This is consistent with the results of unbiasedness tests. So far, there is little evidence rejecting the rational expectation hypothesis for the shorter horizons.

Variables in the information set are not restricted to those tested above. When the second lagged term is added in the case of recent movement of the exchange rate, the number of rejection cases increases dramatically. Results of estimating the following equation are reported in Table 5.D:

$s^{e}(t, k)-s(t+k)=a+b_{1}(s(t-k)-s(t))+b_{2}(s(t-k-1)-s(t-1))+e(t)$

Table 5.D shows rejections for most groups in any horizon. Even if the authogonality test is conducted at the individual level, about threequarters of individuals are judged to be irrational (Table 5.D).

\section{INSERT Table 5 (5.A - 5.D) about here}

In sum, this section shows that most of market participants violate a necessary condition of the rational expectation hypothesis, in that their forecasting methods could benefit from analyzing the relationship between 
their own forecast errors and information available at the time of forecasting. Tables also show that the rational expectation hypothesis can be rejected in the individual level without being detected in the crosssection aggregated (average) data.

\section{Expectational Twist}

\subsection{Introduction to Twist and Consistency}

In this section, the expectation formation of short-vs. Iong-term expectations is explored. Recall Table 1, where the average market participant expected 1.42 percent appreciation in one month, 1.43 percent appreciation in three months, and orly 0.04 percent appreciation in six months. This shows that the short-term expectation is of the bandwagon type, while the long-term expectations show some regressive characteristics. Similar characteristics have also been discovered in other expectation data sets (Frankel and Froot (1987b)). 8

Casual observations from Figure 1 (in the Introduction) suggest that during the wave of appreciation, the JCIF participants also show the extrapolative (bandwagon) expectation for the one-month ahead expectations, while the regressive expectation may be more appropriate for the longer horizon. (This creates a "twist" in arrows of Figure 1.) It seems that a conclusion similar to Frankel and Froot may also be obtained for the JCIF data. It is tempting to replicate their regressions.

However, Frankel and Froot (1987b) ignored the consistency issue of short-and long-term expectation formation: If an expectation formation is internally consistent, a long-term forecast should be identical to a result of sequential substitutions of short-term forecasts, given a function of expectation formation. The consistency becomes a testable hypothesis in the 
form of cross-equation constraints on coefficients of short-and long-term forecast equations. Even in the presense of a twist, one might not reject consistency, if the expectation formation is sufficiently complicated to allow for non-linear forecasts.

This consistency problem is parallel to the cross-equation constraints implied in the context of the interest rate term structure (Sargent (1979)) and in the context of uncovered interest parity (Ito (1988) and Ito and Quah (1988)), Froot and Ito (1988) have applied the test of consistency to data collected by Money Market Service (MMS) for one-week and one-month ahead forecasts and Economist Financial Report for three-, six- and twelvemonth forecasts. In this paper, the same test is applied to the JCIF data, where one-, three- and six-month forecasts are available.

\subsection{An Example of Extrapolative expectation with One Lag}

First, let us consider, following Frankel and Froot (1987b), the extrapolative expectation with one lag:

$s^{e}(t, k)-s(t)=a+b(s(t-1)-s(t))+e(t)$

In ( 5.1$), b<0$ implies $a$ (destabilizing) bandwagon while $b>0$ implies $a$ stabilizing expectation formation. Results are reported in Table 6, which shows that the one percent yen appreciation would make the averagae individual expect a further 0.01 appreciation in one month. However, the Table also implies that the shock would make the same individual to form an expectation of a 0.13 percent depreciation in three months and a 0.22 percent depreciation in six months. Although different groups have different biases, the pattern of coefficients,

$b($ one month $)<b($ three month $)<b($ six month $)$ 
is almost unanimously observed across the board. Hence, we may draw a conclusion. similar to Frankel and Froot (1987b). that the long-term expectation is more stabilizing than the short-term expectation.

INSERT TABLE 6 about here

Next, in order to illustrate the consistency problem. let us assume that one-month and three-month forecasts are formed with the following formulae (with one time period $=4$ weeks):

$$
\begin{aligned}
& s^{e}(t, 1)-s(t)=a+b(s(t-1)-s(t)) \\
& s^{e}(t, 3)-s(t)=A+B(s(t-1)-s(t))
\end{aligned}
$$

or after rearranging terms,

$$
\begin{aligned}
& s^{e}(t, 1)=a+(1-b) s(t)+b s(t-1) \\
& s^{e}(t, 3)=A+(1-B) s(t)+B s(t-1)
\end{aligned}
$$

By iterating the short-term expectation, the expectation of a longer horizon can be obtained. With the information available at time $t$. the following substitution explains the iterated projection.

$$
s^{e}(t+2,1)-a+(1-b) s^{e}(t+2)+b s^{e}(t+1)
$$

where $s^{e}(t+2)-s^{e}(t+1,1)$, and

$$
s^{e}(t+1,1)=a+(1-b) s^{e}(t+1)+b s(t)
$$

where $s^{e}(t+1)=s^{e}(t, 1)$. From $(5.4),(5.6)$ and $(5.7)$, we obtain

$$
s^{e}(t+2,1)=2 a+a(1-b)^{2}+\left(1-b+b^{2}-b^{3}\right) s(t)+\left(b-b^{2}+b^{3}\right) s(t-1)
$$


However, if one-month and three-month expectation formations are consistent with each other, (5.8) should be equivalent to (5.5). Therefore, the following cross-equation constraints should be imposed on a system of equations, $(5.4)$ and $(5.5)$ :

$$
\begin{aligned}
& A=2 a+a(1-b)^{2} \\
& B=b\left(1-b+b^{2}\right)
\end{aligned}
$$

This is the testable hypothesis of consistency between one- and three-month extrapolative expectation with one lag.

It is easy to show that if $b$ is negative, as estimated in Table 6 . equation (5.4), then $B$ has to be also negative. Thus, so long as the extrapolative expectation with one lag is assumed. a twist in expectation is impossible. An unstable bandwagon in the shrot-term $(b<0)$ and a stable weighted average $(B>0)$ in the long-term expectation would be most likely internally inconsistent in the extrapolative expectation with only one lag. Put differently, the assumed formulation is not rich enough to give a chance for the observed twist to be consistent.

\section{$\underline{5.3}$ Consistency Tests}

Next, we adopt a distributed lag expectation formulation with more than two lags, rich enough to produce a twist in expectation. Consider estimating the following one-month and three-month expectation formations (with, again, one period - 4 weeks):

$$
\begin{aligned}
& s^{e}(t, 1)=d+(I+a) s(t)+b s(t-1)+c s(t-2)+u(t) \\
& s^{e}(t, 3)=D+(I+A) s(t)+B s(t-1)+C s(t-2)+v(t)
\end{aligned}
$$

where $u$ and $v$ are independent, random variable representing observation 
errors. After substitution parallel to the preceding subsection. the consistency in this case becomes the following cross-equation constraints:

$$
\begin{aligned}
& D=2 d+a d+b d+(1+a) d^{2} \\
& A=c-1+2(1+a) b+(1+a)^{3} \\
& B=(1+a) c+b^{2}+(1+a) b^{2} \\
& C=c(1+a)^{2}+b c
\end{aligned}
$$

Now, let us consier the consistency requirement for the consistency of the three-month and six-month expectations. Suppose, again, that the expectation formation is of the distributed lag form with two lags:

$$
\begin{aligned}
& s^{e}(t \cdot 3)=d+a s(t)+b s(t-3)+c s(t-6)+u(t) \\
& s^{e}(t, 6)=D+A s(t)+B s(t-3)+C s(t-6)+v(t)
\end{aligned}
$$

The consitency can be expressed as the following cross-equation constraint:

$$
\begin{aligned}
& D=(2+a) d \\
& A=(1+a)^{2}+b-1 \\
& B=(1+a) b+c \\
& C=(1+a) c
\end{aligned}
$$

Each of two sets of cross-equation restrictions $(5.11)-(5.14)$ and (5.17)$(5,20)$ is tested separately, and results are reported in Table 7 . The consistency is overwhelmingly rejected in this formulation, too.

\section{INSERT TABLE 7 about here}

One common reaction from market participants to the result of rejecting the consistency is that they use different economic variables for forecasting the future spot rate with different horizons. They often 
explain to us that the chart (technical) analysis, which is a special case of (univariate) distributed lag expectation formations. is used for the short-term horizon, but other factors come into considerations for the longterm horizon. A list of other factors includes announced balances of payments, inflation rate differentials, interest rate differentials (that is the forward rate under covered interest parity) and fiscal deficits. However, if these factors are relevent in the long-run, they should be relevant in the short-run, though the effect may be small in the short-run. ${ }^{9}$ Of course, if we misspecify the expectation formation, then results in this section is not valid. However, it is not obvious what we would be missing. Instead, results could indicate that market participants, who are buying and selling every minute, are naive enough to give inconsistent forecasts of months ahead.

\section{Concluding Rearks}

In this paper, the newly-available survey data on the expected exchange rate in the Tokyo market were used to test several hypotheses regarding expectation formations. The JCIF data set is better than the data sets previously used by Frankel and Froot $(1987 a, b)$, in that the survey includes expectations of different industries, not only banks and financial institutions but also exporters and importers. Moreover, individual responses can be used to avoid aggregation problem altogether.

Two versions of the rational expectations hypothesis were tested. Following are the major findings of this paper: First, market participants are heterogeneous. Different individuals seem to have constant-term biases in their expectation formations. Among different groups, unbiasedness of expectation was rejected in a few instances for shorter horizons and 
unanimously rejected in the six-month horizons. The orthogonality was soundly rejected. We may conclude that we have a strong evidence aginst rational expectation formation in the Tokyo foreign exchange market.

Then we turn to the issue of consistency between the short-and longhorizon forecasts by the same participants. They are overwhelmingiy rejected, given that the expectation formation is a distributed lag structure with two lags. 


\section{FOOTNOTES}

1. Dominguez (1986) used the Money Market Service (MMS) data form.1983 to 1985 to test a rational expectations hypothesis. Unbiasedness and the independence of forecast errors from the forward premilumere tested. Șhe found that survey forecasts were no better than the spot rate in predictive power and that the rationality was in general rejected. In addition to the MMS data. Frankel and Froot (1987a,b) exploited the survey data collected by Amex Financial Service, Economists, which have a longer sample period and different forecast horizons. They found that expectations do respond to exchange rate changes. Moreover. short-term forecasts are more "destabilizing" than long-term forecasts; that is, the response to the degree of forecasted appreciation in response to appreciation is larger in the short-term horizon than the long-zerm. The risk premilum implied by the data show a premium for dollar-denominated assets.

2

I gratefully acknowledge the help and encouragement from Tomomitsu Oba, Shoji Ochi and Eisuke Sakakibara in allowing me access to the JCIF proprietary data for academic purposes only.

3

About 60 experts in banks and other financial institutions, but not in other sectors, are on the list of the MMS survey. It is not mandatory or insisted by MS that all people on the list respond every week. Depending on who was available for polls, the number of actual reponses varies between 30 and 40 . Therefore, even if individual responses were made available for econometric analysis, frequently missing observations would make the analysis very difficult.

4 The first few surveys were conducted not on Wednesdays but on the middle 
and last business days of the month. However. the survey date was fixed on Wednesday after the fourth observation. A twice-a-month survey means that observations are usually bi-weekly, with a couple of exceptions in a vear. That is, there are 24 , in stead of 26 . observations in the JCIF data in 52 weeks. It is unfortunate that the interval is not fixed. In the following, I disregard the problem arising from a mix of two and three week intervals. The survey started with 42 companies and expanded to the current 44 after the fourth survey in July 1985.

5 Since the micro panel data set was made available on the condition that the anonymity of the source should be honored. it is impossible to aggregate individuals into groups.

6

It is well-known that it takes a long time to have changes in the exchange rate "pass-through" to domestic prices. For example, Japanese exporters absorb some of the exchange rate fluctuations by changing profit margins and the yen-donominated export price, so that the U.S. domestic price of the Japanese products do not fluctuate much; and Japanese importers do not change the Japanese domestic price as much as the change in the exchange rate, while most imports are denominated in the dollar. These pricing behavior is possible when the exporters and importers have differentiated products and/or have substantial adjustment costs for gaining a market share. See Krugman (1987) and Ohno (1988) and references thereof for the theory and empirical evidence on (the lack of) "pass-through."

The group effect of trading companies behaves like that of import industries. One might think that the change in the exchange rate may be neutral for trading companies, since they are just intermediaries of import and export. However, the leading Japanese trading companies handle more 
import than export. In 1983, revenues of the leading nine trading companies are derived from export-oriented activities for $20.0 \%$. import-oriented activities for $23.6 \%$, domestic activities for $40.3 \%$ and trades between foreign countries for 40.3\% (Shinohara (1986: p. 164)). Therefore. a finding that trading companies behave like import companies is not inconsistent with the wishful expectation hypothesis.

7 For the aspects of econometrics, see Mishkin (1983). The same procedure has been applied to the MMS data by Dominguez (1986).

${ }^{8}$ Frankel and Froot (1986b) showed, using the MMS, Economist, and AMEY data set, that short-and long-term expectations seem to have different characteristics. The data set with short-term horizon vields the estimates indicating a bandwagon type (extrapolative), while the data set with a longterm horizon yields the result with more regressive nature. However, the direct comparison of short-term and long-term horizon is limited in their study, due to horizons spread across different data sets and different sample periods.

9

Suppose that uncovered interest parity (no risk premium) holds. An interest rate differential of six percents implies that the exchange rate changes by approximately three percent in six months, which is significant and easy to detenct. However, it predicts only a 0.5 percent change in one month, which is small and may escape detection. However, this does not explain an apparent twist observed in our data. During the sample period, the U.S. interest rates were consistently higher than the Japanese counterparts. However, the expectational twist predicted yen depreciation from the third month to the six month after the time of forecast. 
Dominguez, Kathryn M. "Are Foreign Exchange Forecasts Rational?"

Economics Letters, vol. 21, 1986: $277-281$

Frankel. Jeffrey A. and Kenneth A. Froot "Short-Term and Long-Term Expectations of the Yen/Dollar Exchange Rate: Evidence from Survey Data," Journal of the Japanese and International Economies. vol. 1, 1987: $249-274$.

Frankel, Jeffrey A. and Kenneth A. Froot "Using Survey Data to Test Standard Propositions Regarding Exchange Rate Expectations," American Economic Review, vol.77, 1987: 133-153.

Froot, Kenneth A. and Takatoshi Ito, "On the Consistency of Short-run and Long-run Exchange Rate Expectattions," Natioanl Bureau of Economic Research, working paper no. 2577, May 1988.

Ito, Takatoshi, "Use of (Time-Domain) Vector Autoregressions to Test Uncovered Interest Parity," the Review of Economics and Statistics, vo1. 70, May 1988: pp. 296-305.

Ito, Takatoshi and Danny Quah, "Hypothesis Testing with Restricted Spectral Density Matrices, With an Application to Uncovered Interest Parity," International Economic Review, 1988, forthcoming.

Krugman, Paul, "Pricing to Market when the Exchange Rate Changes," in S.W. Arndt and J.D. Richardson, (eds.) Real-Financial Linkages among Open Economies, MIT Press, 1987.

Mishkin, Frederic S., A Rational Expectations Approach to Macroeconometrics, Chicago: Chicago University Press, 1983.

Ohno, Kenichi, "Export Pricing Behavior of Manufacturing: A U.S.-Japan Comparison," International Monetary Fund, mimeo, June 1988. 
Sargent. Thomas, "A Sote on Maximum Likelihood Estimation of the Rationai Expectations Model of the Term Structure." Journal of Monetary Economics, vol. 5. 1979: 133-143.

Shinohara. Miyohei, (ed.) Lectures on the Japanese Economv (in Japanese). Toyo Keizai Shinpo Sha, 1986 


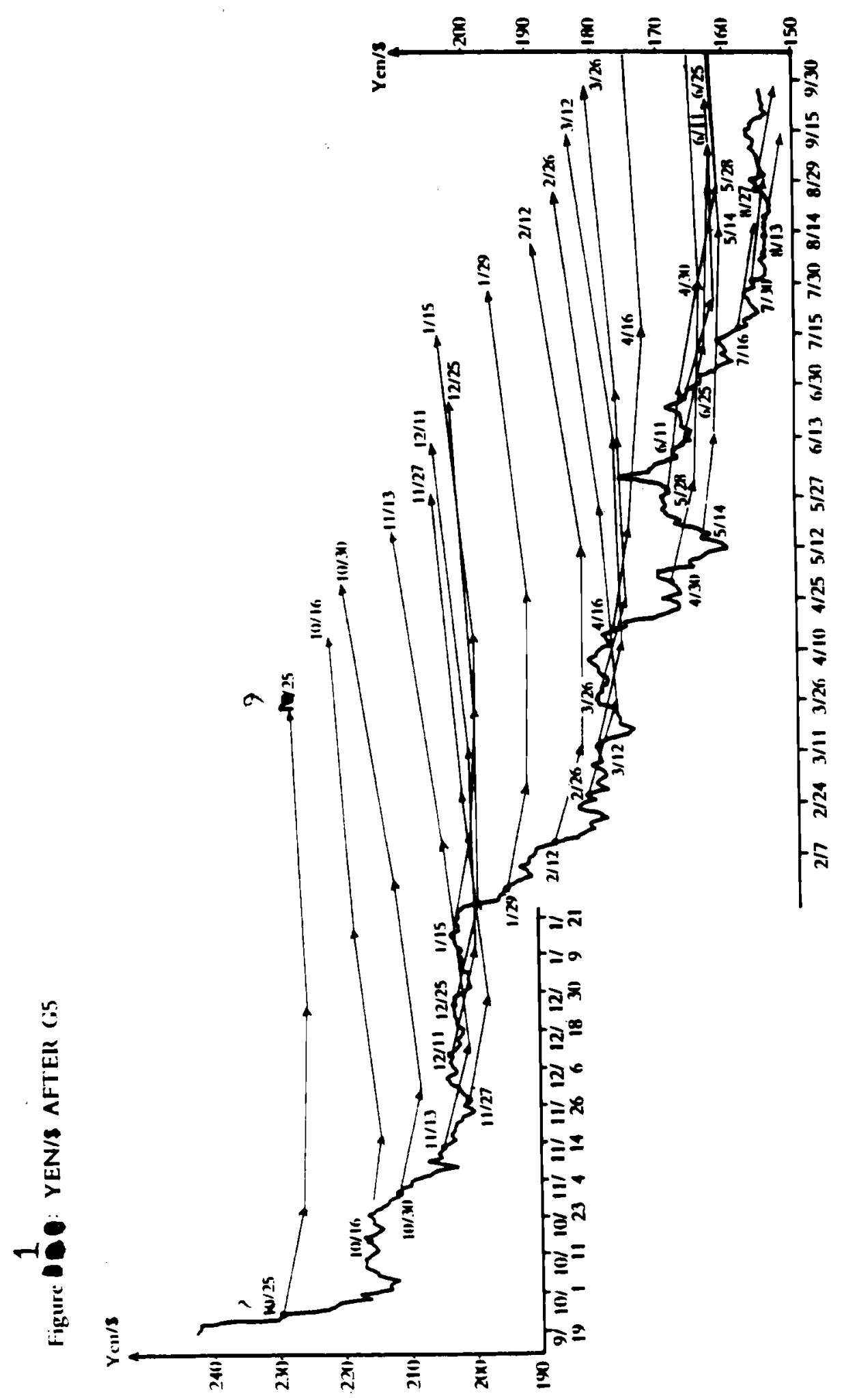


Fjure 2: EXPEETATED SHO

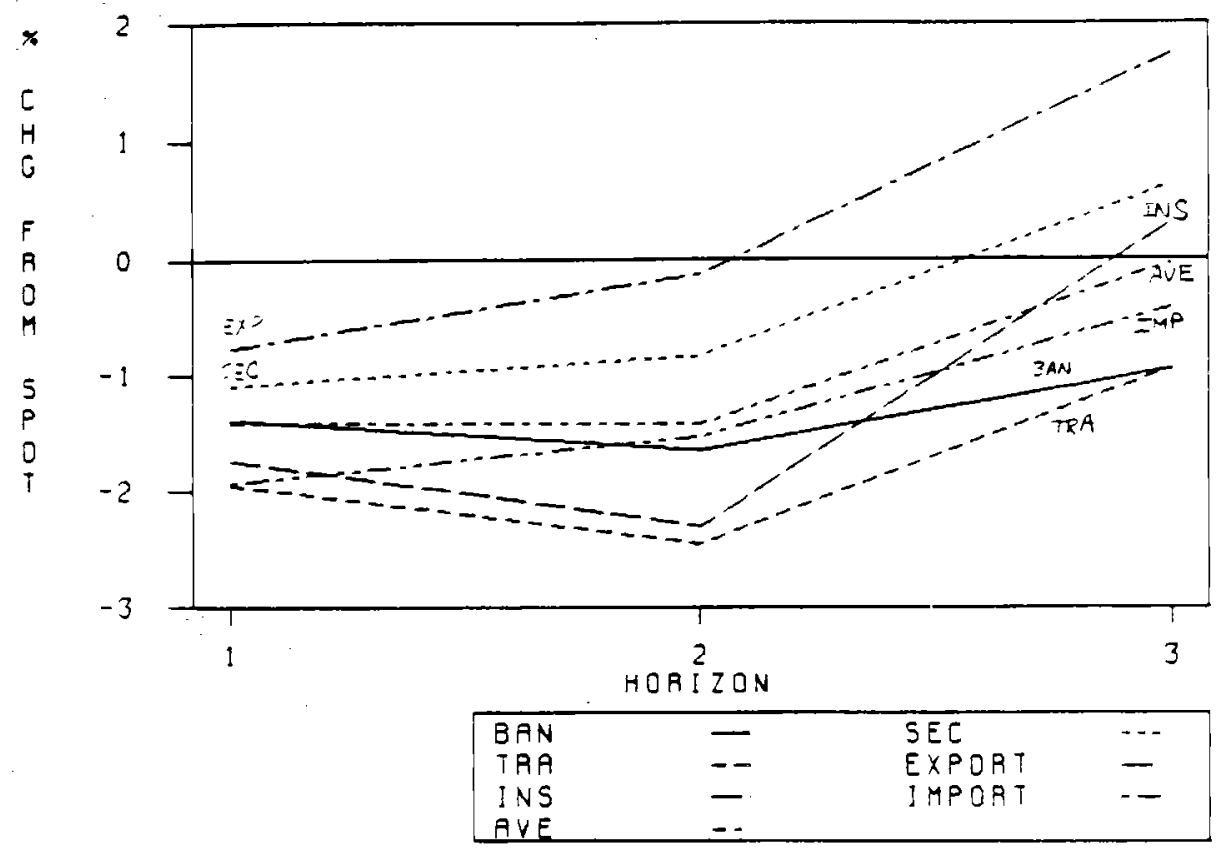


TABle 1: unconditional Expectec Zmarge

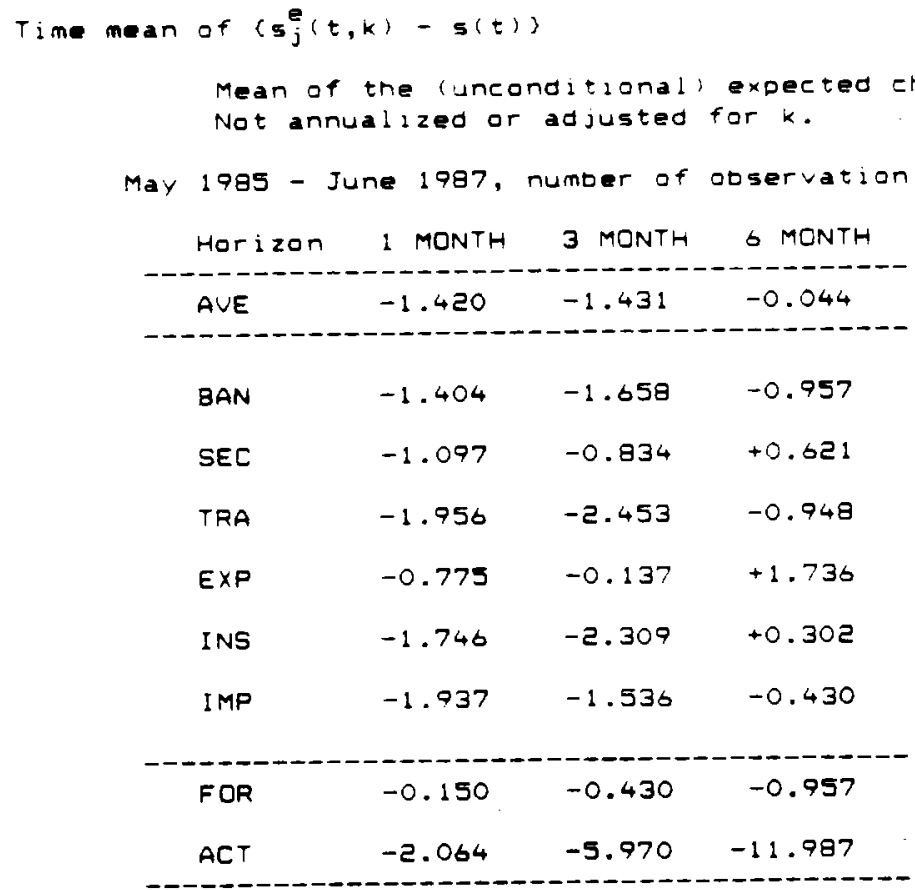

Definition:

AVE: $\stackrel{e}{e}$ in in place of $s_{j}^{e}$
FOR: $f(t, k)$ in place of $s \underset{j}{e}$
ACT: $s(t+k)$ in place of $s e_{j}^{e}$


Distribution among individual respondents of the time mean of forecasted enanges in the exchange rate over the specified horizon HORIZON

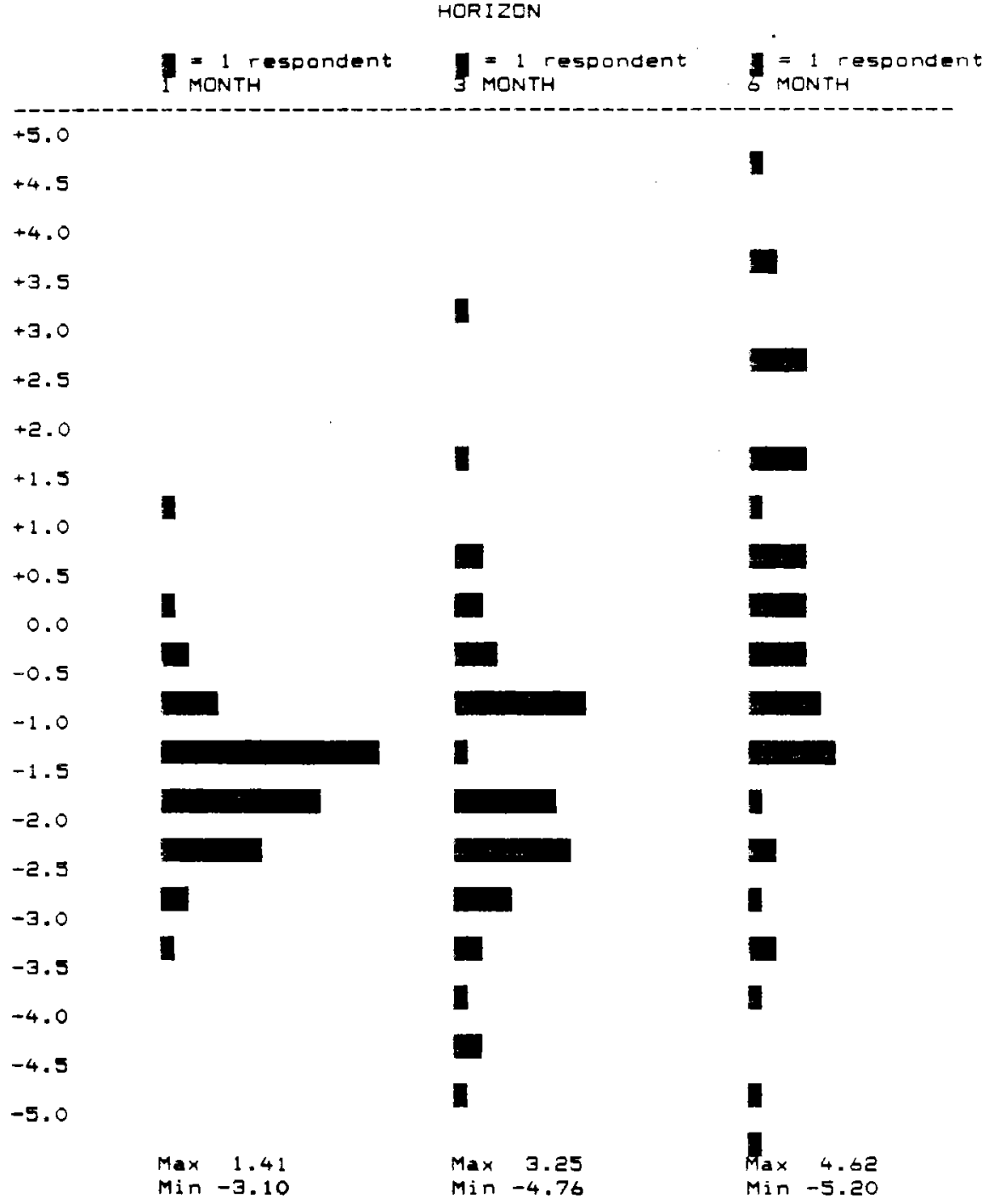


Table 2: Wishful Expectations

(a) Group Deviations from the Total Average, for each horizon,

$$
s_{j}(t,)-S_{A V E}(t)=a_{j}+s_{j}(t)
$$

\begin{tabular}{|c|c|c|c|c|c|c|}
\hline \multirow[b]{2}{*}{ HOR IZON } & \multicolumn{2}{|c|}{$\begin{array}{l}\text { Unit }=\% \\
\text { May } 1985\end{array}$} & \multicolumn{2}{|c|}{ deviation from th } & $\operatorname{cross}-s$ & \multirow{2}{*}{$\begin{array}{l}\text { ection av } \\
6 \text { month } \\
\text { DW or RHO }\end{array}$} \\
\hline & a & $\begin{array}{l}\text { month } \\
\text { DW or RHO }\end{array}$ & 3 & $\begin{array}{l}\text { manth } \\
\text { DW or RHO }\end{array}$ & $\mathbf{a}$ & \\
\hline${ }_{t-s t a t}^{\text {BAN }}$ & $\begin{array}{r}0.017 \\
(0.25)\end{array}$ & $\begin{array}{r}0.284 \\
(2.04)\end{array}$ & $\begin{array}{r}-0.228 \\
(-1.28)\end{array}$ & $\begin{array}{r}0.530 \\
(4.29)\end{array}$ & $\begin{array}{l}-0.941 \\
(-5.74)\end{array}$ & $\begin{array}{r}0.371 \\
(2.81)\end{array}$ \\
\hline $\operatorname{SEC}_{t-5 t a t}$ & $\begin{array}{r}0.305 \\
(1.25)\end{array}$ & $\begin{array}{r}0.438 \\
(3.38)\end{array}$ & $\begin{array}{l}0.561 \\
(1.62)\end{array}$ & $\begin{array}{r}0.421 \\
(3.14)\end{array}$ & $\begin{array}{r}0.743 \\
(1.47)\end{array}$ & $\begin{array}{r}0.446 \\
(3.49)\end{array}$ \\
\hline $\begin{array}{l}\text { TRA } \\
t \text {-stat }\end{array}$ & $\begin{array}{c}-0.536 \\
(-4.98)\end{array}$ & $D W=2.13$ & $\begin{array}{l}-1.022 \\
(-7.56)\end{array}$ & $D W=1.61$ & $\begin{array}{l}-0.908 \\
(-2.57)\end{array}$ & $\begin{array}{r}0.467 \\
(3.61)\end{array}$ \\
\hline $\begin{array}{l}\text { EXP } \\
t-5 t a t\end{array}$ & $\begin{array}{l}0.645 \\
(8.55)\end{array}$ & $D W=2.07$ & $\begin{array}{l}1.294 \\
(12.68) *\end{array}$ & $D W=1.62$ & $\begin{array}{c}1.832 \\
(6.11) *\end{array}$ & $\begin{array}{l}0.435 \\
(3.41)\end{array}$ \\
\hline $\begin{array}{l}\text { INS } \\
t-5 t a t\end{array}$ & $\begin{array}{l}-0.326 \\
(-1.54)\end{array}$ & $\begin{array}{r}0.474 \\
(3.72)\end{array}$ & $\begin{array}{l}-0.815 \\
(-1.93)\end{array}$ & $\begin{array}{r}0.645 \\
(5.86)\end{array}$ & $\begin{array}{r}0.301 \\
(0.54)\end{array}$ & $\begin{array}{r}0.661 \\
(5.99)\end{array}$ \\
\hline $\begin{array}{l}\text { IMP } \\
t-5 t a t\end{array}$ & $\begin{array}{l}-0.517 \\
(-3.76)\end{array}$ & $D W=1.47$ & $\begin{array}{l}-0.079 \\
(-0.29)\end{array}$ & $\begin{array}{r}0.301 \\
(2.17)\end{array}$ & $\begin{array}{l}-0.434 \\
(-1.39)\end{array}$ & $\begin{array}{r}0.422 \\
(3.27)\end{array}$ \\
\hline
\end{tabular}

- shows the "heterogeneous" group at the level of $1 \%$

Table 28: Wishful Expectations II

$$
s_{j}^{e}(t, k)-s_{k}^{e}(t, k)
$$

\begin{tabular}{|c|c|c|c|c|c|c|}
\hline MOR IZON & $a$ & $\begin{array}{l}\text { month } \\
\text { DW or RHO }\end{array}$ & a & $\begin{array}{l}\text { month } \\
\text { DW or RHO }\end{array}$ & $a$ & $\begin{array}{l}6 \text { month } \\
\text { DW or RHO }\end{array}$ \\
\hline $\begin{array}{l}\text { EXP-IMP } \\
\text { t-stat }\end{array}$ & $\begin{array}{c}1.162 \\
(6.73)\end{array}$ & $D W=1.67$ & $\begin{array}{l}1.399 \\
(6.09)\end{array}$ & $D W=1.61$ & $\begin{array}{c}2.271 \\
(4.19)\end{array}$ & $\begin{array}{r}0.460 \\
(3.68)\end{array}$ \\
\hline $\begin{array}{l}\text { EXP-TRA } \\
\text { t-stat }\end{array}$ & $\begin{array}{c}1.181 \\
(7.98)\end{array}$ & $D W=2.21$ & $\begin{array}{c}2.365 \\
(10.31)\end{array}$ & $\begin{array}{r}0.272 \\
(2.01)\end{array}$ & $\begin{array}{c}2.744 \\
(5.09)\end{array}$ & $\begin{array}{r}0.502 \\
(4.04)\end{array}$ \\
\hline
\end{tabular}


Table 2 (continued)

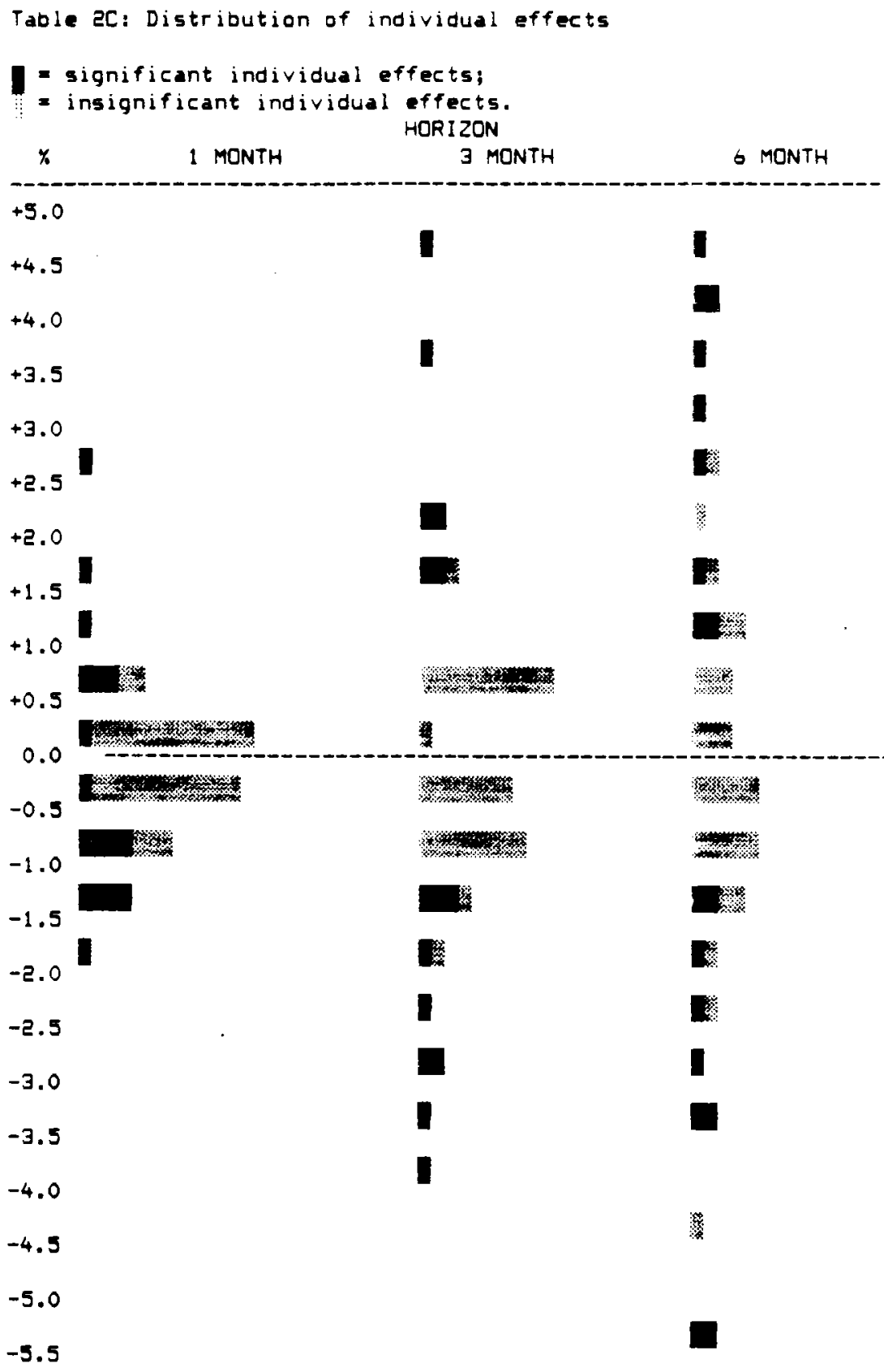




\section{Taole 3: Idiosvncratic effects}

Extrapolative form




Taole 4: Unoiasedness

$s(t+k)-5(t)=a+b\left(s^{2}(t, k)-s(t)\right)$

$H: a=0, b=1$

Generalized Method of Mowents, HObs $=51$

Estimates of $a$ and $b$ and their (standard errors)

HORIZON (k)

1 MONTH

\begin{tabular}{|c|c|c|c|c|c|c|c|c|c|}
\hline & $1 r$ & $\begin{array}{c}\text { MONTH } \\
\text { b }\end{array}$ & CHISO & 3 MONTH & b & CHISe & MONTH & b & $\mathrm{CHI}$ \\
\hline AVE & $\begin{array}{l}-0.028 \\
(0.017)\end{array}$ & $\begin{array}{l}-0.485 \\
(0.969)\end{array}$ & $\begin{array}{l}2.59 \\
.274\end{array}$ & $\begin{array}{l}-0.043 \\
(0.034)\end{array}$ & $\begin{array}{l}1.167 \\
(1.167)\end{array}$ & $\begin{array}{l}5.21 \\
.074\end{array}$ & $\begin{array}{l}-0.119 \\
(0.041)\end{array}$ & $\begin{array}{c}0.908 \\
(0.741)\end{array}$ & $\begin{array}{l}10.09 \\
.006\end{array}$ \\
\hline BAN & $\begin{array}{l}-0.021 \\
(0.015)\end{array}$ & $\begin{array}{l}-0.059 \\
(0.789)\end{array}$ & $\begin{array}{l}2.00 \\
.368\end{array}$ & $\begin{array}{l}-0.044 \\
(0.034)\end{array}$ & $\begin{array}{c}0.945 \\
(1.226)\end{array}$ & $\begin{array}{l}3.69 \\
.159\end{array}$ & $\begin{array}{l}-0.1 \\
10.0\end{array}$ & $\begin{array}{c}0.220 \\
(0.857)\end{array}$ & $\begin{array}{l}7.90 \\
.019\end{array}$ \\
\hline SEC & $\begin{array}{l}-0.015 \\
(0.017)\end{array}$ & $\begin{array}{c}0.517 \\
(0.502)\end{array}$ & $\begin{array}{r}1.97 \\
.373\end{array}$ & $\begin{array}{l}-0.054 \\
(0.025)\end{array}$ & $\begin{array}{c}0.706 \\
(0.292)\end{array}$ & $\begin{array}{l}9.37 \\
.009\end{array}$ & $\begin{array}{l}-0.124 \\
(0.041)\end{array}$ & $\begin{array}{c}0.593 \\
(0.327)\end{array}$ & $\begin{array}{l}9.21 \\
.009\end{array}$ \\
\hline TRA & $\begin{array}{l}-0.036 \\
(0.010)\end{array}$ & $\begin{array}{l}-0.793 \\
(0.371)\end{array}$ & $\begin{array}{r}23.35 \\
.000\end{array}$ & $\begin{array}{l}-0.050 \\
(0.039)\end{array}$ & $\begin{array}{c}0.399 \\
(0.947)\end{array}$ & $\begin{array}{l}2.39 \\
.303\end{array}$ & $\begin{array}{l}-0.110 \\
(0.042)\end{array}$ & $\begin{array}{c}1.038 \\
(0.206)\end{array}$ & $\begin{array}{l}13.34 \\
.001\end{array}$ \\
\hline EXP & $\begin{array}{l}-0.021 \\
(0.010)\end{array}$ & $\begin{array}{c}0.001 \\
(0.747)\end{array}$ & $\begin{array}{l}3.98 \\
.137\end{array}$ & $\begin{array}{l}-0.058 \\
(0.024)\end{array}$ & $\begin{array}{c}0.896 \\
(0.764)\end{array}$ & $\begin{array}{l}9.86 \\
.012\end{array}$ & $\begin{array}{l}-0.143 \\
(0.040)\end{array}$ & $\begin{array}{c}1.307 \\
(0.443)\end{array}$ & $\begin{array}{l}12.86 \\
.002\end{array}$ \\
\hline INS & $\begin{array}{l}-0.030 \\
(0.011)\end{array}$ & $\begin{array}{l}-0.508 \\
(0.472)\end{array}$ & $\begin{array}{r}10.33 \\
.006\end{array}$ & $\begin{array}{l}-0.066 \\
(0.034)\end{array}$ & $\begin{array}{l}-0.264 \\
(0.967)\end{array}$ & $\begin{array}{l}3.92 \\
.141\end{array}$ & $\begin{array}{l}-0.122 \\
(0.039)\end{array}$ & $\begin{array}{c}0.585 \\
(0.665)\end{array}$ & $\begin{array}{l}7.64 \\
.008\end{array}$ \\
\hline$I M P$ & $\begin{array}{l}-0.023 \\
(0.016)\end{array}$ & $\begin{array}{l}-0.139 \\
(0.564)\end{array}$ & $\begin{array}{l}4.76 \\
.092\end{array}$ & $\begin{array}{c}-0.044 \\
(0.027)\end{array}$ & $\begin{array}{c}1.019 \\
(0.352)\end{array}$ & $\begin{array}{r}28.41 \\
.000\end{array}$ & $\begin{array}{l}-0.120 \\
(0.041)\end{array}$ & $\begin{array}{l}-0.016 \\
(0.579)\end{array}$ & $\begin{array}{l}8.69 \\
.013\end{array}$ \\
\hline FOR & $\begin{array}{l}-0.034 \\
(0.013)\end{array}$ & $\begin{array}{l}-8.870 \\
(7.432)\end{array}$ & $\begin{array}{l}8.93 \\
.012\end{array}$ & $\begin{array}{l}-0.104 \\
(0.040)\end{array}$ & $\begin{array}{l}-10.360 \\
(6.702)\end{array}$ & $\begin{array}{l}8.97 \\
.011\end{array}$ & $\begin{array}{l}-0.207 \\
(0.068)\end{array}$ & $\begin{array}{l}-9.159 \\
(3.699)\end{array}$ & $\begin{array}{l}12.25 \\
.002\end{array}$ \\
\hline
\end{tabular}


Tao le 5: Ortmogonali:y

5.A. Past Forecast Errors as an information set

$$
s^{e}(t, k)-s(t+k)=a+b\left(s^{e}(t-k, k)-s(t)\right)+E(t)
$$

$H: \mathbf{a}=0,0=0$, tested oy Generalized Method of Moments, \#0ba=51

Estimates of a and $b$ and their (standard errors)

Chi-square (df $=2$ ) and its (significance level)

HORIZON (k)

1 MONTH 3 MONTH 6 MONTH

a b CHISQ a b o CHISO a b o CHISO

(st.er) (st.er) Signif (st.er) (st.er) Signif (st.er) (st.er) signif

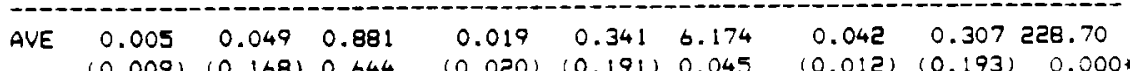

AVE $(0.009)(0.168) 0.644(0.020)(0.191) 0.045(0.012)(0.193)(0.000 *$

\begin{tabular}{|c|c|c|c|c|c|c|c|c|c|}
\hline$B A$ & $\begin{array}{c}0.006 \\
(0.009)\end{array}$ & $\begin{array}{c}-0.002 \\
(0.177)\end{array}$ & $\begin{array}{l}0.608 \\
0.738\end{array}$ & $\begin{array}{c}0.016 \\
(0.019)\end{array}$ & $\begin{array}{c}0.359 \\
(0.180)\end{array}$ & $\begin{array}{l}6.467 \\
0.039\end{array}$ & $\begin{array}{c}0.033 \\
(0.010)\end{array}$ & $\begin{array}{l}0.317 \\
(0.182)\end{array}$ & $\begin{array}{c}61.553 \\
0.000 *\end{array}$ \\
\hline
\end{tabular}

SEC $\quad \begin{array}{lllllllll}0.010 & -0.062 & 1.331 & 0.021 & 0.375 & 10.300 & 0.044 & 0.336 & 373.57\end{array}$

$(0.009)(0.131) 0.514(0.019)(0.149) 0.006 *(0.003)(0.164) \quad 0.000 *$

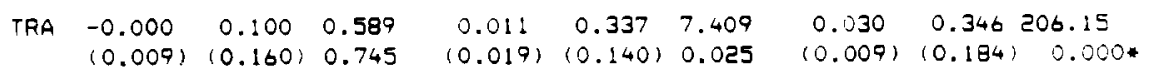

Exp $\quad \begin{array}{ccccccccc}0.011 & 0.093 & 3.729 & 0.029 & 0.321 & 8.075 & 0.059 & 0.293 & 77.482 \\ (0.009) & (0.171) & 0.155 & (0.022) & (0.207) & 0.018 & (0.022) & (0.191) & 0.000 *\end{array}$

INS $\quad \begin{array}{lllllllll}0.001 & 0.159 & 1.649 & 0.020 & 0.200 & 2.117 & 0.065 & 0.179 & 47.248\end{array}$

$\begin{array}{lllllllll}(0.009) & (0.157) & 0.438 & (0.021) & (0.213) & 0.347 & (0.023) & (0.220) & 0.000\end{array}$

IMP $\quad \begin{array}{llllllll}0.000 & 0.046 & 0.080 & 0.017 & 0.352 & 6.006 & 0.047 & 0.244114 .11\end{array}$

$\begin{array}{lllllllllll}(0.009) & (0.184) & 0.961 & (0.020) & (0.218) & 0.050 & (0.012) & (0.206) & 0.000\end{array}$

$\begin{array}{ccccccccc}\text { FOR } & 0.018 & 0.022 & 7.572 & 0.040 & 0.144 & 5.579 & 0.048 & 0.208478 .02 \\ (0.010) & (0.176) & 0.023 & (0.018) & (0.166) & 0.061 & (0.013) & (0.223) & 0.000 \%\end{array}$


5.B: Forward Premium as an information set

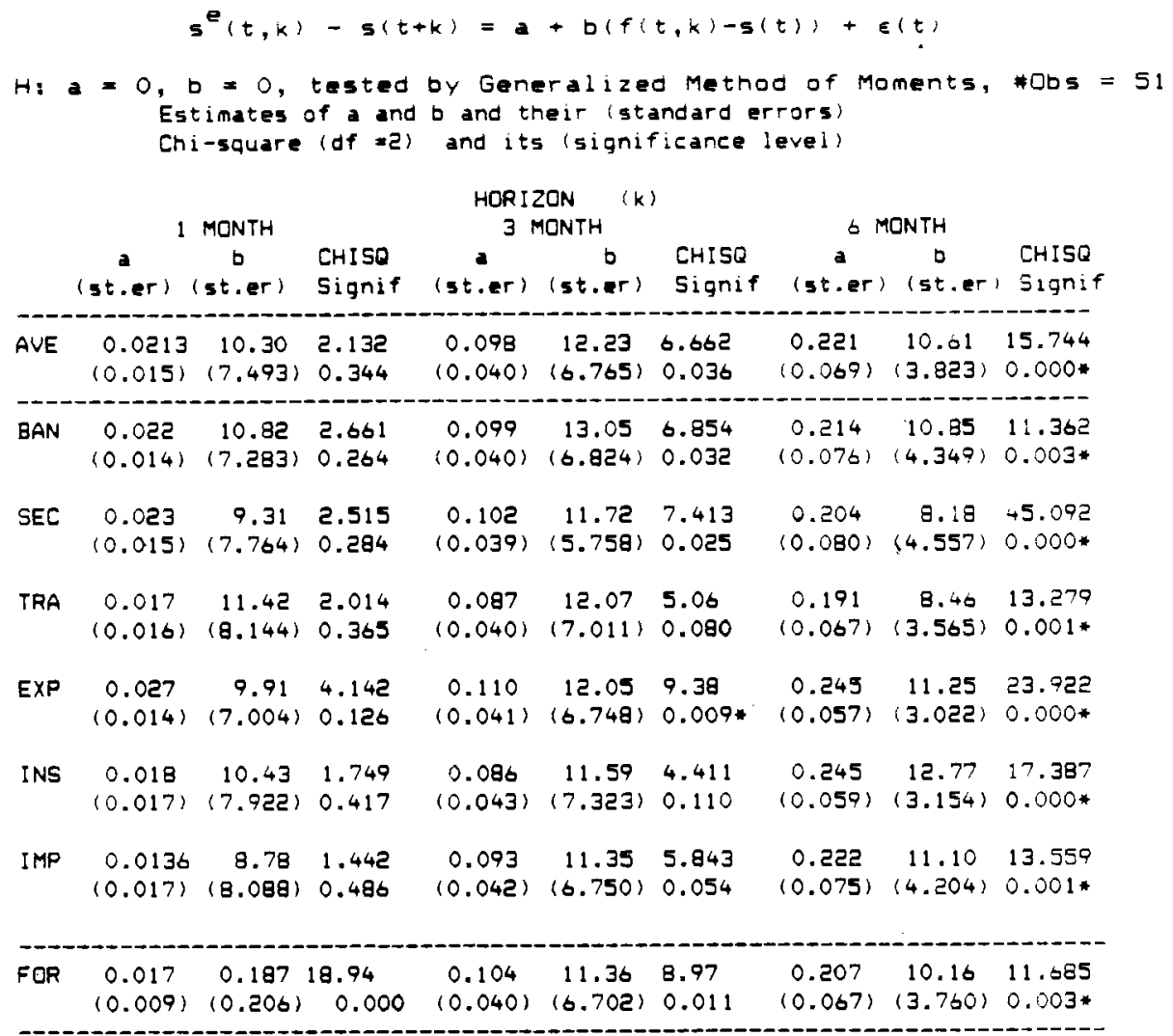


5.C. Past exchange rate changes: One lag version

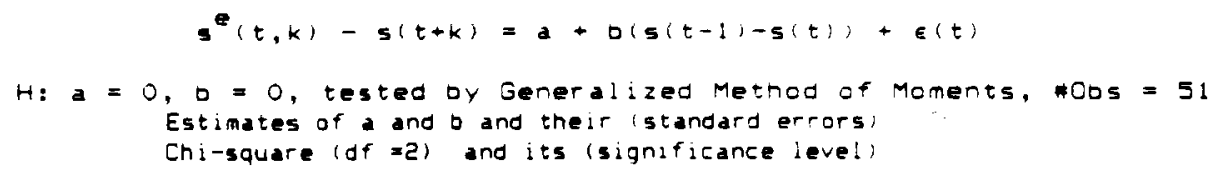

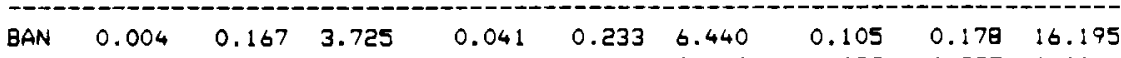

$(0.009)(0.200) \quad 0.155 \quad(0.024)(0.244) \quad 0.040 \quad(0.038)(0.385) \quad 0.000 *$

SEC $\quad \begin{array}{lllllllll}0.008 & 0.069 & 7.534 & 0.047 & 0.389 & 11.327 & 0.120 & 0.318 & 10.274\end{array}$ $(0.009)(0.218) \quad 0.023(0.026)(0.329) 0.003 *(0.039)(0.305) \quad 0.006 *$

\begin{tabular}{|c|c|c|c|c|c|c|c|c|c|}
\hline FOR & $\begin{array}{c}0.017 \\
(0.009)\end{array}$ & $\begin{array}{c}0.187 \\
(0.206)\end{array}$ & $\begin{array}{c}18.94 \\
0.000\end{array}$ & $\begin{array}{r}0.054 \\
(0.024)\end{array}$ & $\begin{array}{r}0.124 \\
(0.221)\end{array}$ & $\begin{array}{l}7.74 \\
0.021\end{array}$ & $\begin{array}{c}0.108 \\
(0.036)\end{array}$ & $\begin{array}{l}-0.142 \\
(0.375)\end{array}$ & $\begin{array}{l}25.93 \\
0.000 *\end{array}$ \\
\hline
\end{tabular}

Number of Cases in Miero Data

1 month 3 month 6 month

Fail to reject $H$ (at $1 x$ )

Reject $H$ 37 26 
Table 5: (continued)

S.D. Past Exchange rate changes: Two lag version

$$
s^{e}(t, k)-s(t+k)=a+b(s(t-1)-s(t))+c(s(t-2)-5(t-1))+\varepsilon(t)
$$

$H: a=0, b=0, C=0$, tested by Generalized Method of Moments, wobs $=51$

Estimates of $b$ and $c$ and their (standard.errors)

Chi-square (of $=3$ ) and its significance level)

HGR:2OK $\{k\}$

1 MONTH 3 MONTH S MONTH

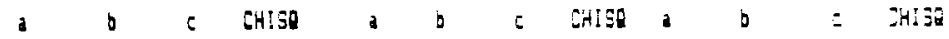

(st.er) (st.er) Signif (st.er) st.er) Signaf st.er! st.er) Sagnat

\begin{tabular}{|c|c|c|c|c|c|c|c|c|c|c|c|c|}
\hline AVE & $\begin{array}{l}.007 \\
(.011 ?\end{array}$ & $\begin{array}{l}.247 \\
(.105)\end{array}$ & $\begin{array}{l}-.323 \\
\{.207\}\end{array}$ & $\begin{array}{l}38.29 \\
.0004\end{array}$ & $\begin{array}{r}.043 \\
1.025 i\end{array}$ & $\begin{array}{r}.330 \\
(.220)\end{array}$ & $\begin{array}{r}-.095 \\
(.093)\end{array}$ & $\begin{array}{l}14.35 \\
.0024\end{array}$ & $\begin{array}{l}.112 \\
.5341\end{array}$ & $\begin{array}{l}183 \\
.2991\end{array}$ & $\begin{array}{l}.174 \\
1.342 !\end{array}$ & $\begin{array}{l}3: .75 \\
.300 t\end{array}$ \\
\hline BAN & $\begin{array}{c}.00 ? \\
(.011)\end{array}$ & $\begin{array}{l}.256 \\
.178)\end{array}$ & $\begin{array}{l}-.355 \\
\{.214\}\end{array}$ & $\begin{array}{r}91 . .10 \\
.000 t\end{array}$ & $\begin{array}{r}.042 \\
.024\}\end{array}$ & $\begin{array}{r}.270 \\
(.235\}\end{array}$ & $\begin{array}{r}-.152 \\
1.1791\end{array}$ & $\begin{array}{l}1.67 \\
.019\end{array}$ & $\begin{array}{l}.103 \\
.0357\end{array}$ & $\begin{array}{l}.129 \\
.31 ?\end{array}$ & $\begin{array}{c}.77 \\
.37 t\end{array}$ & $\begin{array}{l}17.29 \\
.0014\end{array}$ \\
\hline SEC & $\begin{array}{l}.011 \\
1.0111\end{array}$ & $\begin{array}{l}.155 \\
. .205\end{array}$ & $\begin{array}{c}-.339 \\
(.187\}\end{array}$ & $\begin{array}{r}22.18 \\
.0004\end{array}$ & $\begin{array}{r}.047 \\
1.0277\end{array}$ & $\begin{array}{r}.392 \\
(.308)\end{array}$ & $\begin{array}{r}.028 \\
1.191\}\end{array}$ & $\begin{array}{l}12.10 \\
.007\end{array}$ & $\begin{array}{l}.1: 9 \\
.397)\end{array}$ & $\begin{array}{l}263 \\
.273)\end{array}$ & $\begin{array}{l}.22 ! \\
: .293\end{array}$ & $\begin{array}{r}20.7 \\
.813\end{array}$ \\
\hline IRA & $\begin{array}{l}.000 \\
1.012)\end{array}$ & $\begin{array}{c}.227 \\
{[.194)}\end{array}$ & $\begin{array}{l}-.219 \\
(.221)\end{array}$ & $\begin{array}{l}11.80 \\
.009+\end{array}$ & $\begin{array}{r}.032 \\
(.025)\end{array}$ & $\begin{array}{r}.290 \\
\{.264\}\end{array}$ & $\begin{array}{r}.001 \\
(.079)\end{array}$ & $\begin{array}{c}0.49 \\
.090\end{array}$ & $\begin{array}{l}.104 \\
i .034\end{array}$ & $\begin{array}{l}.389 \\
.268\end{array}$ & $\begin{array}{l}.189 \\
.339\end{array}$ & $\begin{array}{l}i 2.37 \\
. j p e t\end{array}$ \\
\hline EXP & $\begin{array}{l}.013 \\
.011\}\end{array}$ & $\begin{array}{l}.312 \\
\{.197\}\end{array}$ & $\begin{array}{l}-.318 \\
(.209)\end{array}$ & $\begin{array}{l}31.89 \\
.0004\end{array}$ & $\begin{array}{r}.055 \\
(.025)\end{array}$ & $\begin{array}{r}.387 \\
(.175)\end{array}$ & $\begin{array}{r}.022 \\
(.050)\end{array}$ & $\begin{array}{l}18.60 \\
.000+\end{array}$ & $\begin{array}{l}.13 ! \\
.031 !\end{array}$ & $\begin{array}{l}.190 \\
.342)\end{array}$ & $\begin{array}{l}.130 \\
1.2911\end{array}$ & $\begin{array}{l}43.57 \\
.0004\end{array}$ \\
\hline INS & $\begin{array}{l}.003 \\
(.012 !\end{array}$ & $\begin{array}{l}.307 \\
(.193)\end{array}$ & $\begin{array}{l}-.327 \\
\{.213\rangle\end{array}$ & $\begin{array}{l}27.96 \\
.0004\end{array}$ & $\begin{array}{r}.036 \\
(.024)\end{array}$ & $\begin{array}{r}.376 \\
(.195)\end{array}$ & $\begin{array}{l}-.243 \\
. .084\}\end{array}$ & $\begin{array}{l}60.07 \\
.3004\end{array}$ & $\begin{array}{l}.117 \\
1.032\}\end{array}$ & $\begin{array}{c}.249 \\
(.289)\end{array}$ & $\begin{array}{l}.05 n \\
(.41) 2\end{array}$ & $\begin{array}{c}37.05 \\
.9004\end{array}$ \\
\hline Inp & $\begin{array}{l}.003 \\
(.012)\end{array}$ & $\begin{array}{l}.139 \\
(.208)\end{array}$ & $\begin{array}{l}-.342 \\
(.205)\end{array}$ & $\begin{array}{l} \pm 5.8 ? \\
.001 \%\end{array}$ & $\begin{array}{r}.042 \\
1.024]\end{array}$ & $\begin{array}{r}.374 \\
(.239)\end{array}$ & $\begin{array}{r}-.121 \\
(.129)\end{array}$ & $\begin{array}{l}34.94 \\
.0004\end{array}$ & $\begin{array}{l}.106 \\
1.0341\end{array}$ & $\begin{array}{l}.304 \\
1.3101\end{array}$ & $\begin{array}{l}.245 \\
1.413 !\end{array}$ & $\begin{array}{l}10,+3 \\
.001+\end{array}$ \\
\hline JR & $\begin{array}{c}.019 \\
(.011)\end{array}$ & $\begin{array}{l}.259 \\
(.182)\end{array}$ & $\begin{array}{l}-.287 \\
(.209)\end{array}$ & $\begin{array}{r}149.22 \\
.0001\end{array}$ & $\begin{array}{r}.057 \\
(.025)\end{array}$ & $\begin{array}{r}.188 \\
\text { (. .223) }\end{array}$ & $\begin{array}{l}-.255 \\
i .0741\end{array}$ & $\begin{array}{l}54.57 \\
.0004\end{array}$ & $\begin{array}{c}.110 \\
(.034)\end{array}$ & $\begin{array}{l}-.088 \\
(.317)\end{array}$ & $\begin{array}{l}-.216 \\
(.322)\end{array}$ & $\begin{array}{c}3 i .+2 \\
.0004\end{array}$ \\
\hline
\end{tabular}

Number of cases among Micro Data

$\begin{array}{llll} & 1 \text { month } & 3 \text { month } & 6 \text { month } \\ \text { Fail to reject } H(1 \%): 11 & 22 & 21 \\ \text { Reject } H(1 \%): & 33 & 22 & 23\end{array}$


Table o: Expectation Formation

Extrapolative expectation with one lag

$$
\mathbf{s}_{j}(t, k)-s(t)=a+b(s(t-1)-s(t))+c(t)
$$

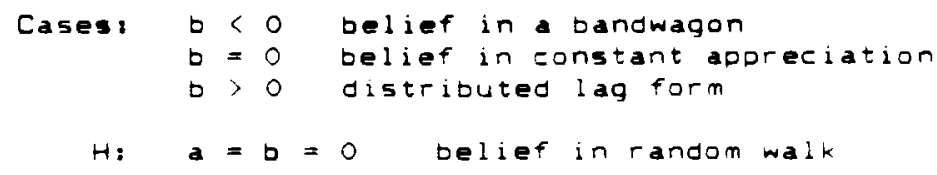

\begin{tabular}{|c|c|c|c|c|c|c|c|c|c|}
\hline & & & $\mathrm{HC}$ & $\mathbf{N}$ & & & & & \\
\hline & $1 \%$ & MONTH & & $3 \mathrm{M}$ & VTH & & 6 & DNTH & \\
\hline & a & b & $\mathrm{CH} I \mathrm{SO}$ & a & $b$ & $\mathrm{CHISO}$ & a & b & CHISO \\
\hline AVE & $\begin{array}{l}-.015 \\
(.002)\end{array}$ & $\begin{array}{l}-.011 \\
(.035)\end{array}$ & $\begin{array}{l}49.42 \\
.000\end{array}$ & $\begin{array}{l}-.017 \\
(.005)\end{array}$ & $\begin{array}{l}.137 \\
(.050)\end{array}$ & $\begin{array}{l}9.60 \\
.000\end{array}$ & $\begin{array}{l}-.002 \\
(.009)\end{array}$ & $\begin{array}{l}.220 \\
(.066)\end{array}$ & $\begin{array}{l}5.49 \\
0.002\end{array}$ \\
\hline BAN & $\begin{array}{l}-.014 \\
(.001)\end{array}$ & $\begin{array}{c}-.008 \\
(.044)\end{array}$ & $\begin{array}{l}62.85 \\
.000\end{array}$ & $\begin{array}{l}-.019 \\
(.005)\end{array}$ & $\begin{array}{l}.087 \\
(.056)\end{array}$ & $\begin{array}{l}6.75 \\
.003\end{array}$ & $\begin{array}{l}-.011 \\
(.009)\end{array}$ & $\begin{array}{l}.134 \\
(.077)\end{array}$ & $\begin{array}{l}2.06 \\
.139\end{array}$ \\
\hline SEC & $\begin{array}{l}-.011 \\
(.003)\end{array}$ & $\begin{array}{c}-.058 \\
(.061)\end{array}$ & $\begin{array}{l}8.05 \\
.001\end{array}$ & $\begin{array}{l}-.011 \\
(.005)\end{array}$ & $\begin{array}{l}.149 \\
(.108)\end{array}$ & $\begin{array}{l}2.46 \\
.097\end{array}$ & $\begin{array}{l}.006 \\
(.009)\end{array}$ & $\begin{array}{l}.224 \\
(.141)\end{array}$ & $\begin{array}{l}1.69 \\
.195\end{array}$ \\
\hline TRA & $\begin{array}{l}-.020 \\
(.002)\end{array}$ & $\begin{array}{l}-.029 \\
(.068)\end{array}$ & $\begin{array}{l}69.67 \\
.000\end{array}$ & $\begin{array}{l}-.027 \\
(.004)\end{array}$ & $\begin{array}{l}.067 \\
(.096)\end{array}$ & $\begin{array}{r}21.42 \\
.000\end{array}$ & $\begin{array}{l}-.011 \\
(.006)\end{array}$ & $\begin{array}{l}.194 \\
(.120)\end{array}$ & $\begin{array}{l}2.41 \\
.101\end{array}$ \\
\hline EXP & $\begin{array}{l}-.009 \\
(.001)\end{array}$ & $\begin{array}{l}.061 \\
(.039)\end{array}$ & $\begin{array}{l}18.82 \\
.000\end{array}$ & $\begin{array}{l}-.004 \\
(.004)\end{array}$ & $\begin{array}{l}.168 \\
(.068)\end{array}$ & $\begin{array}{l}3.19 \\
.050\end{array}$ & $\begin{array}{l}.016 \\
(.010)\end{array}$ & $\begin{array}{l}.304 \\
(.095)\end{array}$ & $\begin{array}{l}6.77 \\
.003\end{array}$ \\
\hline INS & $\begin{array}{l}-.018 \\
(.003)\end{array}$ & $\begin{array}{l}.015 \\
(.067)\end{array}$ & $\begin{array}{l}17.20 \\
.000\end{array}$ & $\begin{array}{l}-.027 \\
(.005)\end{array}$ & $\begin{array}{c}.237 \\
(.068)\end{array}$ & $\begin{array}{r}18.42 \\
.000\end{array}$ & $\begin{array}{l}-.001 \\
(.010)\end{array}$ & $\begin{array}{l}.376 \\
(.111)\end{array}$ & $\begin{array}{l}5.79 \\
.006\end{array}$ \\
\hline IMP & $\begin{array}{l}-.018 \\
(.003)\end{array}$ & $\begin{array}{l}-.134 \\
(.075)\end{array}$ & $\begin{array}{l}29.43 \\
.000\end{array}$ & $\begin{array}{c}-.019 \\
(.006)\end{array}$ & $\begin{array}{l}.285 \\
(.108)\end{array}$ & $\begin{array}{l}6.95 \\
.002\end{array}$ & $\begin{array}{l}-.008 \\
(.008)\end{array}$ & $\begin{array}{l}.288 \\
(.110)\end{array}$ & $\begin{array}{l}3.60 \\
.035\end{array}$ \\
\hline JR & $\begin{array}{l}-.001 \\
(.000)\end{array}$ & $\begin{array}{l}-.007 \\
(.007)\end{array}$ & $\begin{array}{l}18.28 \\
.000\end{array}$ & $\begin{array}{c}-.004 \\
(.001)\end{array}$ & $\begin{array}{l}.030 \\
(.011)\end{array}$ & $\begin{array}{r}15.59 \\
.000\end{array}$ & $\begin{array}{c}-.011 \\
(.003)\end{array}$ & $\begin{array}{l}-.169 \\
(.011)\end{array}$ & $\begin{array}{l}7.89 \\
.001\end{array}$ \\
\hline
\end{tabular}

$\begin{array}{lrrrr}\text { Number of Cases In Miero Data, } & & \\ & \text { Horizon } & 1 \text { month } & 3 \text { month } & 6 \text { month } \\ \text { b } \gg 0 \text { sig. } & 3 & 8 & 10 \\ \text { b }>0 \text { insig. } & 18 & 29 & 31 \\ \text { b }<0 \text { insig. } & 20 & 7 & 3 \\ \text { b }<0 \text { sig. } & 3 & 0 & 0\end{array}$


Table 7: Consistency Tests

Ine-month (k=2) vs. three-month $(k=6)$ expectations

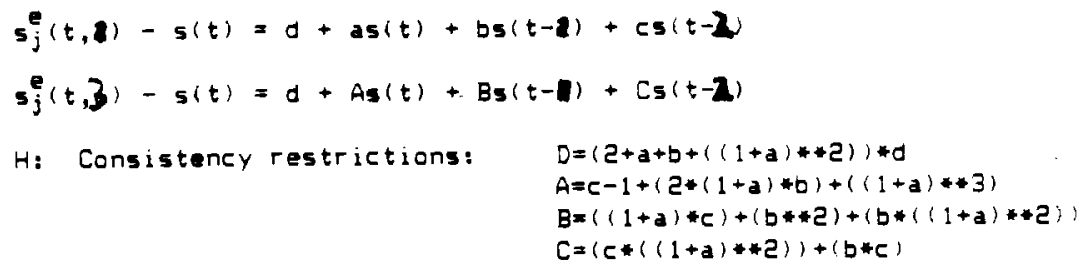

Estimates and (standard errors)

1 MONTH (OLS)

$\begin{array}{lllllllll}0 & a & b & C & D & A & B & C & C H I S O\end{array}$

\begin{tabular}{|c|c|c|c|c|c|c|c|c|c|}
\hline & $d$ & $\mathbf{a}$ & b & c & $D$ & $A$ & B & C & CHISO \\
\hline AVE & $\begin{array}{l}-.0261 \\
(.0090)\end{array}$ & $\begin{array}{l}.0003 \\
(.0001)\end{array}$ & $\begin{array}{l}.0001 \\
(.0002)\end{array}$ & $\begin{array}{l}-.0003 \\
(.0001)\end{array}$ & $\begin{array}{l}-.0254 \\
(.0071)\end{array}$ & $\begin{array}{l}-.0008 \\
(.0071)\end{array}$ & $\begin{array}{l}.0005 \\
(.0001)\end{array}$ & $(.0003)$ & $\begin{array}{c}2182.1 \\
.000\end{array}$ \\
\hline BAN & $\begin{array}{l}-.0202 \\
(.0061)\end{array}$ & $\begin{array}{l}.0002 \\
(.0002)\end{array}$ & $(.0000)$ & $\begin{array}{l}-.0003 \\
(.0001)\end{array}$ & $\begin{array}{l}-.0272 \\
(.0062)\end{array}$ & $\begin{array}{l}-.0005 \\
(.0001)\end{array}$ & $\begin{array}{l}.0000 \\
(.0001)\end{array}$ & $\begin{array}{l}.0005 \\
(.0001)\end{array}$ & $\begin{array}{l}493.0 \\
.000\end{array}$ \\
\hline SEC & $\begin{array}{l}-.0061 \\
(.0102)\end{array}$ & $(.0005)$ & $\begin{array}{l}-.0003 \\
(.0003)\end{array}$ & $\begin{array}{l}-.0003 \\
(.0002)\end{array}$ & $\begin{array}{l}-.0056 \\
(.0152)\end{array}$ & $\begin{array}{l}-.0014 \\
(.0004)\end{array}$ & $(.0001)$ & $\begin{array}{l}.0013 \\
(.0001)\end{array}$ & $\begin{array}{l}399.7 \\
.000\end{array}$ \\
\hline TRA & $\begin{array}{l}-.0388 \\
(.0093)\end{array}$ & $\begin{array}{l}.0001 \\
(.0002)\end{array}$ & $(.0003)$ & $\begin{array}{l}-.0003 \\
(.0002)\end{array}$ & $\begin{array}{l}-.0471 \\
(.0073)\end{array}$ & $\begin{array}{l}-.0007 \\
(.0002)\end{array}$ & $(.0009)$ & $\begin{array}{l}-.0001 \\
(.0001)\end{array}$ & $\begin{array}{c}12403.3 \\
.000\end{array}$ \\
\hline EXP & $\begin{array}{l}-.0190 \\
(.0056)\end{array}$ & $\begin{array}{l}.0000 \\
(.0001)\end{array}$ & $\begin{array}{l}.0002 \\
(.0002)\end{array}$ & $\begin{array}{l}-.0002 \\
(.0001)\end{array}$ & $\begin{array}{l}-.0142 \\
(.0050)\end{array}$ & $\begin{array}{l}-.0011 \\
(.0001)\end{array}$ & $\begin{array}{l}.0010 \\
(.0002)\end{array}$ & $(.0002)$ & $\begin{array}{l}776.2 \\
.000\end{array}$ \\
\hline INS & $\begin{array}{l}-.0497 \\
(.0096)\end{array}$ & $\begin{array}{l}.0004 \\
(.0003)\end{array}$ & $\begin{array}{l}.0006 \\
(.0003)\end{array}$ & $\begin{array}{l}-.0008 \\
(.0002)\end{array}$ & $\begin{array}{l}-.0423 \\
(.0085)\end{array}$ & $\begin{array}{l}-.0004 \\
(.0002)\end{array}$ & $\begin{array}{l}.0010 \\
(.0002)\end{array}$ & $\begin{array}{l}-.0005 \\
(.0001)\end{array}$ & $\begin{array}{l}428.6 \\
.000\end{array}$ \\
\hline IMP & $\begin{array}{l}-.0346 \\
(.0114)\end{array}$ & $\begin{array}{l}.0006 \\
(.0003)\end{array}$ & $\begin{array}{l}-.0005 \\
(.0004)\end{array}$ & $\begin{array}{l}-.0000 \\
(.0003)\end{array}$ & $\begin{array}{l}-.0148 \\
(.0208)\end{array}$ & $\begin{array}{l}-.0010 \\
(.0002)\end{array}$ & $\begin{array}{l}.0002 \\
(.0003)\end{array}$ & $\begin{array}{c}.0008 \\
(.0002)\end{array}$ & $\begin{array}{c}3718.9 \\
.000\end{array}$ \\
\hline $\mathrm{J} R$ & $\begin{array}{l}-.0053 \\
(.0009)\end{array}$ & $\begin{array}{l}.0000 \\
(.0000)\end{array}$ & $\begin{array}{l}-.0000 \\
(.0000)\end{array}$ & $\begin{array}{c}.0000 \\
(.0000)\end{array}$ & $\begin{array}{l}-.0116 \\
(.0008)\end{array}$ & $\begin{array}{l}.0001 \\
(.0000)\end{array}$ & $\begin{array}{c}-.0001 \\
(.0000)\end{array}$ & $\begin{array}{l}.0000 \\
(.0000)\end{array}$ & $\begin{array}{l}53.6 \\
.000\end{array}$ \\
\hline
\end{tabular}

In Micro Data, for only 2 individuals, $H$ is failed to be rejected. 
Three-month $(k=6)$ vs. Twelve-month $(k=12)$ expectations

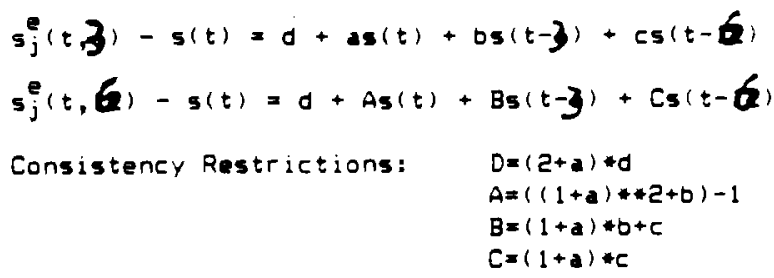

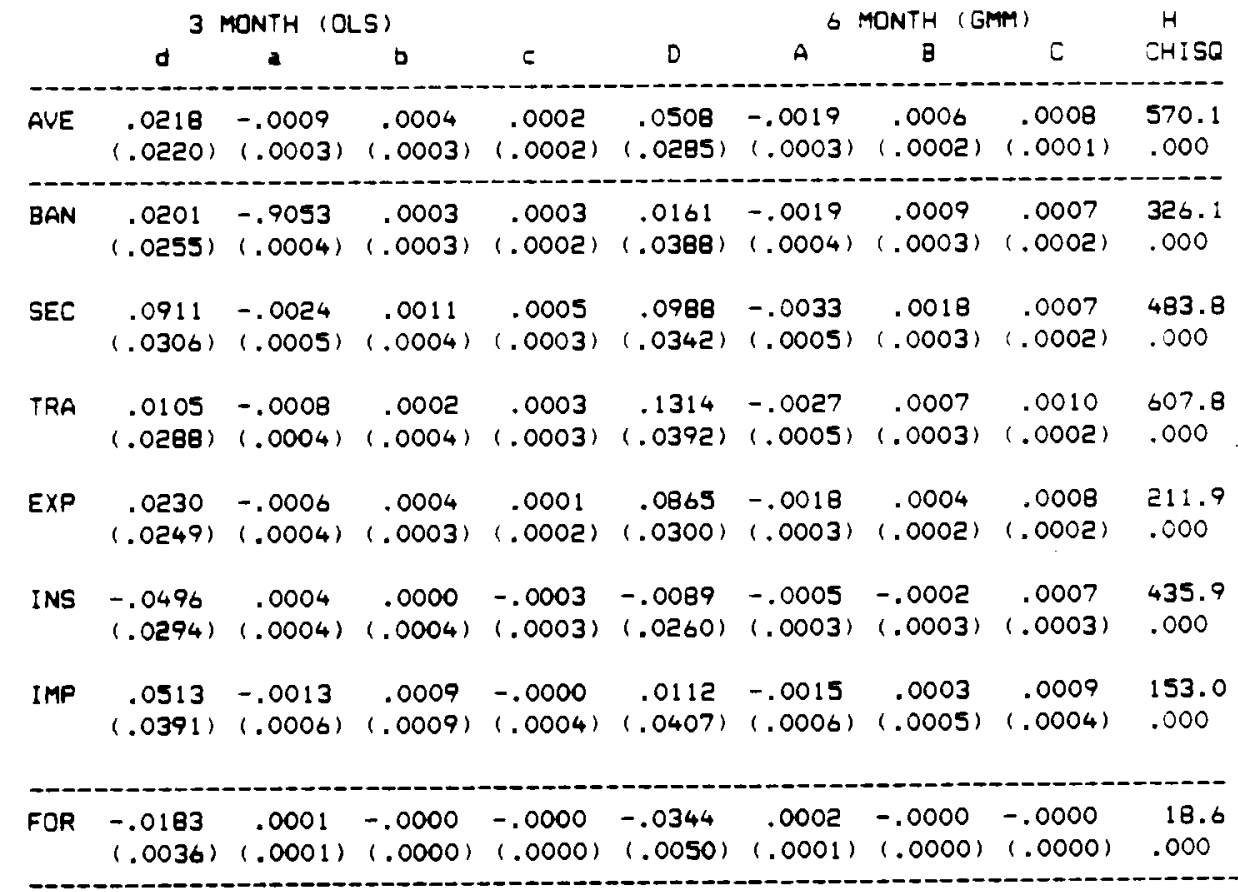

In Micro Data, for only 2 individuals, $H$ is failed to be rejected. 